\title{
SUSTAINABLE CRITERIA FOR WATER SAVING TECHNOLOGIES INTRODUCTION
}

\author{
Felix Stolberg \\ Yuliya Vystavna \\ National Academy of Municipal Economy in Kharkiv, Ukraine
}

\begin{abstract}
Focus is on scientific and economic background, and implementation of resource saving measures in the municipal economy, which would allow significant reduction of negative impacts on the environment caused by municipal facilities and other infrastructures, as well as to increase economic efficiency in municipal economy through resources and financial flows management. The new approach to the evaluation of resource saving technologies for needs of municipal economy has been developed on basics of economics and environmental indicators.
\end{abstract}

The aim of this research paper is twofold: (1) to determine precautionary measures leading to reduction in public water use, and (2) to develop appropriate indicators and criteria for assessing the sustainability of measures for minimization of water use. The proposed indicators will help owners of office buildings and investors to make decision in implementation of such environmentally sound technologies as resource saving measures. In order to achieve the goal of this research, extensive analysis of data was done. Principal data sources were the Ukrainian National Surface Water Monitoring reports, provided by Regional Office of the National Hydro-meteorological Service in Kharkiv, databases on point sources emission provided by Kharkiv Municipal Water Works (Municipal Enterprise "KP "Voda") and Wastewater Treatment Facilities (Municipal Enterprise "Kharkivkomunochystvod"), data from the Kharkiv Municipal Energy and Heat Supply Company ("Kharkivteploenergo"), and the State Committee of Statistics' year fact books.

Options for dealing with water minimization are generated according such approaches as changes of human behavior, water control implementation and water saving technologies introduction. Criteria were developed by the result of preliminary research of water minimization factors. The approach to criteria development is based on hierarchy, consisting of small number of high level primary criteria, which would cascade down to a large number of more specific, secondary criteria. According to the chosen criteria the necessary data should be collected to use records, individual and group interviews, social survey. After the data collection, indicators development the procedure of the decision support will be done using the multi-criteria analysis.

\section{KEYWORDS}

Urban water management; Water minimization; Sustainable criteria; Water efficiency options; Decision-making process. 


\section{INTRODUCTION}

The urban areas with high density of population demand dramatically large quantities of energy, water, and raw materials. This usually turns into environmental pollution, ecosystems degradation, natural resources deficit and allocation. Water is a crucially important issue in urban planning, livelihood security, resources allocation, food supply, and access to sanitation. Thus, water quantity and quality are important aspects of water management concerning the pollution control as economic and environmental saf ety of any country. Due to intensive exploitation and inadequate pollution control many of big cities are facing degradation of natural water resources. Disproportion in economic and water resources potentials of a region and significant artificial loads lead to depletion and pollution of water sources and, as a consequence, to water deficiency. Effective urban water management should include accountability for harm course, planning based on well-defined goals and criteria, and consideration of all possible means in the environmental impact assessment. Decision-making process should endorse a precautionary approach to risk management and, in particular, should proceed to the adoption of the appropriate precautionary measures.

The aim of this research paper is twofold: (1) to determine precautionary measures leading to reduction in public water use, and (2) to develop appropriate indicators and criteria for assessing the sustainability of measures for minimisation of water use.

\section{OBJECTIVES}

Different approaches to criteria generation and their use for sustainable urban water management have been developed in a number of studies. The scientific group of the Swedish Foundation for Strategic Environmental Research proposed a set of sustainable criteria and sub-criteria under five categories: health and hygiene, socio-cultural, environmental, economic, functional and technical [1]. Dutch scientists developed sustainable criteria for the comparison of different wastewater treatment technologies (cited from: Ashley et al [2]). The American Society of Civil Engineers and the United Nations Educational, Scientific and Cultural Organization (UNESCO) proposed economic, environmental and ecological criteria and guidelines for the use in a systems assessment of sustainable water resources planning with involvement of multiple stakeholders. The group of researchers from the UK developed a multi-criteria decision-support system in the framework of the Sustainable Water Industry Asset Resource Decisions (SWARD) project to assist water services in assessing relative sustainability of water/wastewater system asset development decisions. This concept is based on hierarchy and introduces small number of high level primary criteria that cascade down to a larger number of more specific, secondary criteria classified under four categories: economic, environmental, social, and technical [2]. The main principles of the SWARD were used to develop the decision procedures for water minimisation projects in this research.

Ukraine is one of the largest countries in Europe with population of about 47 million. However, comparing to Europe's countries, Ukraine is a country with substantial shortage of water resources. The average annual availability of water resources is $1700 \mathrm{~m}^{3}$ per capita. For example, such indicator for France is 4570 , and for Sweden - $24000 \mathrm{~m}^{3}$ per capita [3]. At the same time, daily water consumption in urban areas is more than 350 litres per capita, and water leakage at water transportation is more than $2 \mathrm{~km}^{3}$ per year. Additionally, more than $10500 \mathrm{~km}^{3}$ of wastewaters discharged annually cause increasing pollution of the surface water resources in Ukraine. Problems of urban water management and water minimisations in this research were examined and assessed for the case of the city of Kharkiv. 
Kharkiv is the second largest city in Ukraine with population of about 1,35 million (2001). Urban water supply is done mostly from surface water sources ( $85 \%$ of total consumption). The Kharkiv region is not reach in water resources. There are about 200 rivers in the region but most of them are small to very small. Today, households, office and residential building are major consumers of water, accounting for about $75 \%$ of total water supply by the municipal water company making up to 375 L per capita per day [4]. Such high level of water consumption in the city that with scarce water resources leads to such environmental problems as decrease in the amount of natural water resources due to high water consumption, pollution of surface water with wastewater discharge, and environmental contamination from the wastewater treatment sludge generation and accumulation.

One of the ways to predict the large-scale water crisis is to develop the local scheme of efficient water resources management and to reduce water use by major water consumers. In order to achieve the goal of this research, extensive analysis of data was done. Principal data sources were the Ukrainian National Surface Water Monitoring reports, provided by Regional Office of the National Hydro-meteorological Service in Kharkiv, databases on point sources emission provided by Kharkiv Municipal Water Works (Municipal Enterprise "KP 'Voda"') and Wastewater Treatment Facilities (Municipal Enterprise "Kharkivkomunochystvod"), data from the Kharkiv Municipal Energy and Heat Supply Company ("Kharkivteploenergo"), and the State Committee of Statistics' year fact books.

The method of the research includes: the economic, environmental and social assessment of the impact of the high water consumption on municipal economy, proposition of different options to reduce inefficient water use, generation of indicators and criteria based on the results of the assessment.

\section{RESULTS}

\subsection{Urban water systems in Kharkiv city, Ukraine}

Water supply and water treatment systems in Kharkiv have a long history and are welldeveloped. Water is supplied to the city from groundwater sources and rivers. The water treatment system includes the mechanical and chlorinating processes. Two wastewater treatment plants are operated in Kharkiv using the mechanical and biological treatment processes. About $1 \mathrm{mln} \mathrm{m}^{3}$ of treated wastewater is discharged daily to surface waters from the Kharkiv municipal wastewater treatment plants (MWWTP). At present, water quality in all the rivers of the region does not meet the Ukrainian Water Sanitation Standards by such indices as ammonium nitrogen, oil products, phenol, nitrates, nitrites, copper, total iron, and zinc [5]. Alternative water source like springs are polluted with heavy metals, hydrocarbons and other organic and inorganic pollutants and, thus, cannot be widely used for public water supply without quite expensive pre-treatment. Urban water systems are characterised with high level of water losses from distribution networks (ca. 54\%) due to obsolete and somewhat inefficient equipment and low motivation of consumers to water saving. According to the World Bank Group's recommendations [6], to be considered as efficient water distribution networks should have losses less than $15-20 \%$. Water metering is applied in only $10 \%$ of Kharkiv households. The water problems in Kharkiv as well as in a whole Ukraine have been insufficiently addresses by public bodies and stakeholders. Stakeholders are not experienced or involved in any form of public awareness programmes to conserve water resources. 
One of the ways to prevent water crisis and improve the water sustainability is to make water use more efficient by introduction and promotion of water saving techniques in household and public buildings.

\subsection{Environmental, economic, technical and social factors of water minimization}

During the last decade a decrease of wastewaters volume to be treated by mechanical and biological processes on MWWTP was observed. Such change connected to current economic situation in Ukraine and decrease in domestic industrial production. Preliminary estimations give the figure of $83 \%$ of total Kharkiv's municipal wastewaters coming from households and only $17 \%$ from industries. Such changes influenced both the economic activity of MWWTP and environmental safety of treatment processes. The environmental balance was developed for Kharkiv MWWTP to estimate the energy and material flows of the wastewater treatment processes.

Table1. Annual environmental balance of MWWTP (Kharkiv, 2002).

\begin{tabular}{cc|cc}
\hline \multicolumn{2}{c|}{ Inflow } & \multicolumn{2}{c}{ Outflow } \\
\hline Wastewaters, $\mathrm{m}^{3}$ & 246705100 & Treated wastewaters, $\mathrm{m}^{3}$ & 246705100 \\
\hline $\begin{array}{c}\text { Wastewater } \\
\text { contaminants, } \mathrm{t}\end{array}$ & 184201,53 & Total contaminants, $\mathrm{t}$ & 145369,2 \\
\hline Electricity, $\mathrm{kWh}$ & 90000361,5 & \multicolumn{2}{|l}{$\begin{array}{c}\text { Wastes after mechanical } \\
\text { treatment, } \mathrm{m}^{3}\end{array}$} \\
\hline Chemicals (chlorine), $\mathrm{t}$ & 3118,7 & \multicolumn{2}{c}{ Wastes after biological treatment, } \\
& & $\mathrm{t}$ & 39359,16 \\
\hline Water, $\mathrm{m}^{3}$ & 323800 & \multicolumn{2}{c}{ Other wastes, $\mathrm{t}$} \\
\hline & & Emissions: & 834,2 \\
\hline & & nitrogen dioxide, $\mathrm{t}$ & 8,92 \\
\hline & & sulphur dioxide, $\mathrm{t}$ & 4,18 \\
\hline & & carbon dioxide, $\mathrm{t}$ & 2,42 \\
\hline
\end{tabular}

The balance model was developed to establish numeric agreement between water quality in surface water flow and quality and quantity of wastewater discharged from MWWTP. It takes into account amount of wastewaters discharged from both the municipal wastewater treatment facilities and other non-point and point sources of pollution, as well as in-stream surface water quality [5]. The model was used to generate and assess a set of environmental sustainable criteria. Concerning the economic criteria, their definition mostly depends on the local situation and stakeholders' motivation. Application of the economic criteria and indicators was discussed in terms of data availability and validity in order to analyse their usefulness for the assessment of introduction of water minimisation technologies [7].

In 2005 a total of 154 households were interviewed in the city of Kharkiv with the purpose to study consumer behaviour regarding customers' satisfaction with urban water services; water metering; consumers' ability to pay for water services; motivation towards implementation of water-saving technologies. Most of the interviewed people $(86 \%)$ used the water from the municipal water distribution network and their households were connected to the municipal sewage works. These people were chosen as a focus group for further analysis of responds. $95 \%$ of the sample lived in apartments and only $5 \%$ in individual houses. Average occupation 
was 2,6 persons per household. All households were equipped with shower/bath and flash toilet. Only $7 \%$ of households had water metering with average water consumption level at 160 litres per day per person, and such residents were found most motivated to water saving. Water expenses (including hot and cold water supply and water sewage services) averaged in about 60 Ukrainian Hryvnyas (UAH) ${ }^{1}$ per person per month that made about $15-16 \%$ of the average household income. Only $56 \%$ households paid for water services in time. About $67 \%$ of households were not satisfied with the quality of water services, mostly because of periodical breaks in cold and hot water supply and lower water temperature.

\subsection{Sustainable criteria and options of water minimization}

Following the survey, a set of sustainable water minimisation indicators and criteria was generated. These were organised in the hierarchical way with defined primary and secondary criteria [8].

Following criteria and indicators development, a set of the options for water minimisation in public sector was proposed (Table 2) basing on the multimode approach: (A) human behaviour changes, (B) implementation of water control and $(C)$ introduction of water saving technologies. As a reference point, the option of (D) doing nothing was estimated, too.

Table 2. Options of water minimization in public sector.

\begin{tabular}{ccc}
\hline Option & Measures & Primary objective \\
\hline 1 (A) & $\begin{array}{c}\text { Promotion of sustainability and } \\
\text { efficiency in water use. Public } \\
\text { campaigns }\end{array}$ & $\begin{array}{c}\text { To encourage a change in water consumption } \\
\text { behaviour towards water saving }\end{array}$ \\
\hline 2 (B) & $\begin{array}{c}\text { Implementation of domestic water } \\
\text { metering }\end{array}$ & $\begin{array}{c}\text { To provide for the control of water use and for } \\
\text { water saving motivation }\end{array}$ \\
\hline 3 (B) & Leakage control & $\begin{array}{c}\text { To provide for the leakage monitoring and its } \\
\text { reduction in time and for water supply } \\
\text { minimisation }\end{array}$ \\
\hline 4 (C) & $\begin{array}{c}\text { Introduction of water saving } \\
\text { technologies (spray tap) }\end{array}$ & To reduce water use in a public sector \\
\hline
\end{tabular}

\section{Case Study: Water management in the office buildings in the city of Kharkiv, Ukraine}

The case study on application of the sustainable criteria to water minimisation options to a 5storied office building in the city of Kharkiv was conducted in 2005-2006.

The office building with total area of $7594 \mathrm{~m}^{2}$ located in the Central District of the city was built in 1956 and has been used as the main office of the R\&D Institute "ENERGOATOM" with the staff of 405 people. The annual water use was $4109 \mathrm{~m}^{3}$, and the owner of the building was interested in water minimisation because of high water bill, and the needs to invest into repairing and replacing the obsolete sanitation and water supply equipment. At present time the old (from 1975) water supply system and sanitary equipment are used in the building. There is no water management system at the organisation, and the staffs generally are low motivated to water minimisation.

After preliminary water and resource use auditing three main options of water minimisation were proposed: option A - organising the public campaign of water minimisation (seminars,

${ }^{1} 100 \mathrm{UAH}$ equal to 14,7 EURO as by 30.04 .2007 
handouts); option B - development of the system of water management and auditing; option C - replacing the old water equipment (tap; toilet, urinal) with new, more efficient one. The three options were evaluated with the application of the indicators and sustainable criteria (Table 3).

Comparative economic and environmental cost-benefit analysis showed that positive results could be achieved from the implementation of water-saving measures in the office building. Such measures do not call for high capital investments, have a low payback period, and are environment-friendly. The investors could support the implementation of either a whole set of measures or just some of them according to the priority. The reduction of water use will lead consequently to reduction in electricity supply for water treatment, heating and distribution. The owner could develop and support the local water management scheme for the building and it will be a part of environmental policy and will also bring the positive economic effect.

Table 3. Sustainable criteria for implementation of different options of water minimisation in a 5-storied office building in the city of Kharkiv and their evaluation.

\begin{tabular}{|c|c|c|c|c|c|}
\hline Primary criteria & $\begin{array}{c}\text { Secondary } \\
\text { criteria }\end{array}$ & $\begin{array}{c}\text { Indicator's } \\
\text { value }\end{array}$ & Option A & Option B & Option C \\
\hline \multicolumn{6}{|c|}{ Economic criteria } \\
\hline \multirow{3}{*}{$\begin{array}{c}\text { Water } \\
\text { minimisation } \\
\text { costs }\end{array}$} & $\begin{array}{c}\text { Total } \\
\text { investments }\end{array}$ & euro & 120 & 200 & 2500 \\
\hline & $\begin{array}{l}\text { Operational and } \\
\text { Maintenance } \\
\text { costs }\end{array}$ & euro/year & 50 & 50 & 20 \\
\hline & Repair costs & euro/year & 0 & 0 & 100 \\
\hline Financial Risk & Payback period & years & 1.5 & 1.5 & 5.5 \\
\hline \multirow[t]{2}{*}{ Affordability } & $\begin{array}{l}\text { Water bill } \\
\text { reduction }\end{array}$ & euro/year & 70 & 115 & 365 \\
\hline & $\begin{array}{l}\text { Electricity bill } \\
\text { reduction }\end{array}$ & euro/year & 11 & 17 & 55 \\
\hline \multicolumn{6}{|c|}{ Environmental criteria } \\
\hline \multirow[t]{3}{*}{$\begin{array}{l}\text { Resource } \\
\text { utilisation }\end{array}$} & $\begin{array}{c}\text { Water use } \\
\text { minimisation }\end{array}$ & $\mathrm{m}^{3} /$ year & 280 & 460 & 940 \\
\hline & $\begin{array}{l}\text { Leakage } \\
\text { reduction }\end{array}$ & $\mathrm{m}^{3} /$ year & - & - & 520 \\
\hline & $\begin{array}{l}\text { Electricity use } \\
\text { reduction for } \\
\text { water supply }\end{array}$ & kWh/year & 33.6 & 55.2 & 112.8 \\
\hline $\begin{array}{c}\text { Environmental } \\
\text { impact }\end{array}$ & $\begin{array}{l}\text { Air emissions } \\
\text { reduction }\end{array}$ & $\mathrm{kg} /$ year & 1.7 & 2.8 & 5.7 \\
\hline \multicolumn{6}{|c|}{ Social criteria } \\
\hline Responsibility & $\begin{array}{c}\text { Participation in } \\
\text { change } \\
\text { behaviour }\end{array}$ & $\%$ people & 40 & 55 & 15 \\
\hline \multicolumn{6}{|c|}{ Technical criteria } \\
\hline Adaptability & $\begin{array}{l}\text { Costs of } \\
\text { removal or } \\
\text { adding to the } \\
\text { water supply } \\
\text { system }\end{array}$ & euro & 0 & 0 & 100 \\
\hline
\end{tabular}


The comparison economic and environment cost-benefit analysis show real positive results of water-saving measures implementation in the office building. Such measures don't need high capital investments, have a low payback period, have the positive economic effect and environmentally friendly. The investors can implement the measures in complex or according the priority scale. The reduction of water use leads to electricity use reduction for water heating and supply. The owner can develop and support the local water management scheme for the building and it will be a part of environmental policy and also has the positive economic effect.

\section{CONCLUSIONS}

Sustainable criteria and indicators for the local water management can be use by stakeholders in the decision-making process. Such criteria include not only economic but also the social and environmental factors of water minimisation. The developed concept offers the opportunity to assess the environmental, economic and social impacts of implementation of different water minimisation measures in public sector. Of course, not all stakeholders can be involved in the decision-making process, and the selection of stakeholders influences the result. Moreover, input data could be incorrect and/or incomplete during the water use auditing, indicators estimation and so on.

The proposed approach can be used as not only the part of the local urban water management but also at the level of a whole region. The proposed criteria are to be used in the assessment of water minimisation in the public sector of the entire city of Kharkiv. The impacts of reduction of water use on the urban environment, social and economic situation will be estimated, and forecast of changes in water and wastewater treatment processes due to water minimisation will be executed, as well.

The results of study have shown low public participation in solving the environmental problems in the city of Kharkiv. It can be explained with insufficient environmental education on the sustainable development issues, in particular, efficient water and other natural resources management. Promotions of environmentally friendly lifestyles do not yet take place in Ukraine. However, social partnership is a top priority issue in a movement towards sustainable development, one of core aspects of which is resource conservation and efficiency. The enthusiasm of citizens whatever low level of which is observed at present should be transferred into concrete actions. This definitely will pay for the increased economic growth while reducing the environmental footprints.

\section{ACKNOWLEDGEMENT}

The authors like to thank Dr. Blackwood D. and D. Gilmour, Urban Water Technology Centre of the University of Abertay Dundee, Scotland, for the intellectual support and materials about SWARD provided for this study.

\section{REFERENCES}

[1] Hellström D., Jeppsson U., E. Kärrman, 2000. A framework for systems analysis of sustainable urban water management. Environmental Impact Assessment Review, 20 (3): 311-322.

[2] Ashley, R., Blackwood, D., Butler, D., Jowitt, P., 2004. Sustainable water service: A procedural guide. IWA Publishing, 235pp. 
[3] Shevelev, F. A., Orlov, T. A., 1987. Vodosnabzheniye bol'shikh gorodov mira [Water supply of big cities of the World], 'Stroyizdat' Publ. House, Moscow, 351 pp. (in Russian).

[4] Petrosov, V. A., 1998. Vodosnabzheniye goroda Khar'kova [Water Supply of the city of Kharkiv], Kharkiv, 40 pp. (in Russian).

[5] Vystavna, Y., 2005. The Balanced Model of the Sustainable Water Consumption in a Public Sector in Ukraine. In: W. Hogland (Ed). ECO-TECH'05: Conference on Waste to Energy, Bioremediation and Leachate Treatment. The Second Baltic Symposium on Environmental Chemistry, November 28-30, 2005, Kalmar, Sweden, P. 455-461.

[6] World Bank Group, 2000. Data on urban water and sanitation.

[7] Vystavna, Y., 2006. Organizatsionno-ekonomicheskiye mechanizmy optimizatsii sistemy vodosnabzheniya g. Khar'kova [Organisational and economic tools of sustainable water supply in the city of Kharkiv], Mekhanizmy Ekonomichnogo Regulyuvannya [Mechanisms of Economic Regulation], No. 4, P. 54-68. (in Russian).

[8] Vystavna, Y., 2006. Economic and Environment Assessment of Resource Saving Technologies in Municipal Economy. The Proceeding of Youth International Conference (Ecobaltic-2006), S. Petersburg, Russia 27-29 June 2006. 